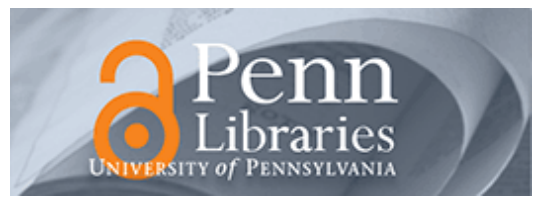

University of Pennsylvania

ScholarlyCommons

Management Papers

Wharton Faculty Research

4-2007

\title{
U.S. Multinational Activity Abroad and U.S. Jobs: Substitutes or Complements?
}

Ann E. Harrison

University of Pennsylvania

Margaret S. McMillan

Clair Null

Follow this and additional works at: https://repository.upenn.edu/mgmt_papers

Part of the Business Administration, Management, and Operations Commons, and the International Business Commons

\section{Recommended Citation}

Harrison, A. E., McMillan, M. S., \& Null, C. (2007). U.S. Multinational Activity Abroad and U.S. Jobs:

Substitutes or Complements?. Industrial Relations: A Journal of Economy and Society, 46 (2), 347-365.

http://dx.doi.org/10.1111/j.1468-232X.2007.00471.x

This paper is posted at ScholarlyCommons. https://repository.upenn.edu/mgmt_papers/58

For more information, please contact repository@pobox.upenn.edu. 


\title{
U.S. Multinational Activity Abroad and U.S. Jobs: Substitutes or Complements?
}

\author{
Abstract \\ Critics of globalization claim that firms are being driven by the prospects of cheaper labor and lower labor \\ standards to shift employment abroad. Yet the evidence, beyond anecdotes, is slim. This paper reports \\ stylized facts on the activities of U.S. multinationals at home and abroad for the years 1977 to 1999 . We \\ focus on firms in manufacturing and services, two sectors that have received extensive media attention \\ for supposedly exporting jobs. Using firm-level data collected by the Bureau of Economic Analysis (BEA) \\ in Washington, D.C., we report correlations between U.S. multinational employment at home and abroad. \\ Preliminary evidence based on the operations of these multinationals suggests that the sign of the \\ correlation depends on the crucial distinction between affiliates in high-income and low-income countries. \\ For affiliates in high-income countries there is a positive correlation between jobs at home and abroad, \\ suggesting that foreign employment of U.S. multinationals is complementary to domestic employment. \\ For firms that operate in developing countries, employment has been cut in the United States, and affiliate \\ employment has increased. To account for firm size, substitution across firms and entry and exit, we \\ aggregate our data to the industry level. This exercise reveals that the observed "complementarity" \\ between U.S. and foreign jobs has been driven largely by a contraction across all manufacturing sectors. \\ It also reveals that foreign employment in developing countries has substituted for U.S. employment in \\ several highly visible industries, including computers, electronics, and transportation. The fact that there \\ were U.S. jobs lost to foreign affiliates in key sectors, despite broad complementarity in hiring and firing \\ decisions between U.S. parents and their affiliates, helps explain why economists view the impact of \\ globalization on U.S. jobs as benign despite negative news coverage for declining industries. \\ Disciplines \\ Business Administration, Management, and Operations | International Business
}




\title{
US Multinational Activity Abroad and US Jobs: Substitutes or
}

\section{Complements?*}

\author{
Ann E. Harrison ${ }^{\wedge}$ \\ UC Berkeley \\ NBER
}

\author{
Margaret S. McMillan* \\ Tufts University \\ NBER
}

\author{
Clair Null \\ UC Berkeley
}

March 2006

\begin{abstract}
*For assistance with data the authors would like to thank Raymond Mataloni, Joan Hamory, Fritz Foley and Stanley Watt. For helpful comments we wish to thank David Card and the fellows at the Radcliffe Institute for Advanced Study, especially Larry Katz. For financial assistance the authors gratefully acknowledge the National Science Foundation. McMillan acknowledges the Radcliffe Institute for Advanced Study for both financial support and time to devote to this project. Views expressed in this paper are those of the authors and do not necessarily reflect those of the Bureau of Economic Analysis. The statistical analysis of firm-level data on U.S. multinational companies was conducted at the International Investment Division, Bureau of Economic Analysis, U.S. Department of Commerce under arrangements that maintain legal confidentiality requirements. The views expressed in this paper are those of the authors and do not reflect official positions of the U.S. Department of Commerce.
\end{abstract}

\footnotetext{
^ 329 Giannini Hall, UC Berkeley, Berkeley, California 94720, 510-643-9676, email: harrison@ are.berkeley.edu

* Tufts University Department of Economics, 617627 3137, email: mmcmilla@ tufts.edu Ann Harrison acknowledges support from the Giannini Foundation at UC Berkeley.
} 


\title{
US Multinational Activity Abroad and US Jobs: Substitutes or Complements?
}

\author{
Ann E. Harrison \\ University of California Berkeley \\ NBER
}

\author{
Margaret S. McMillan \\ Tufts University \\ NBER
}

\author{
Clair Null \\ UC Berkeley
}

\begin{abstract}
Critics of globalization claim that firms are being driven by the prospects of cheaper labor and lower labor standards to shift employment abroad. Yet the evidence, beyond anecdotes, is slim. This paper reports stylized facts on the activities of US multinationals at home and abroad for the years 1977 to 1999 . We focus on firms in manufacturing and services, two sectors that have received extensive media attention for supposedly exporting jobs. Using firm level data collected by The Bureau of Economic Analysis (BEA) in Washington, D.C., we report correlations between US multinational employment at home and abroad. Preliminary evidence based on the operations of these multinationals suggests that the sign of the correlation depends upon the crucial distinction between affiliates in high-income and low-income countries. For affiliates in high-income countries there is a positive correlation between jobs at home and abroad suggesting that foreign employment of US multinationals is complementary to domestic employment. For firms that operate in developing countries, employment has been cut in the US and affiliate employment has increased. To account for firm size, substitution across firms and entry and exit, we aggregate our data to the industry level. This exercise reveals that the observed "complementarity" between US and foreign jobs has been driven largely by a contraction across all manufacturing sectors. It also reveals that foreign employment in developing countries has substituted for US employment in several highly visible industries, including computers, electronics and transportation. The fact that there were US jobs lost to foreign affiliates in key sectors, despite broad complementarity in hiring and firing decisions between US parents and their affiliates, helps to explain why economists view the impact of globalization on US jobs as benign despite negative news coverage for declining industries.
\end{abstract}




\section{Introduction}

Critics of globalization claim that US firms are shutting down factories at home and shifting employment abroad to countries with cheaper labor and lower labor standards. Yet the evidence, beyond anecdotes, is slim. Are US employers really shifting employment abroad, expanding affiliate employment at the cost to US manufacturing employment? The limited evidence on this question is inconclusive. Working papers by Brainard and Riker (1997a, 1997b) find that jobs abroad do substitute for jobs at home but the effect is small. They also find that employment in developing countries by US firms is very sensitive to the cost of labor. A more recent working paper by Desai, Foley and Hines (2005) finds the opposite - an increase in the number of jobs abroad is associated with an increase in the number of jobs at home. Amiti and Wei (2005) also find evidence to support the notion that US multinationals treat US and foreign labor as complementary: when a US multinational firm expands employment abroad, employment at home also increases. In a now infamous press release for the Economic Report of the President (2004), Greg Mankiw pointed out that US outsourcing is good for the US economy.

Despite the rosy expectations of most of these academic economists, union leaders and journalists are less optimistic. The newspapers are filled with anecdotes of plants closing operations in the US to relocate operations abroad. While most of these stories emphasized the manufacturing sector in the past, interest has recently shifted to services. Stories about textile and garment factories closing in Texas and elsewhere have been replaced by fears of US programming jobs being lost to highly skilled Indians in Bangalore. In France, fears of lost jobs were one factor that recently motivated voters to reject a proposal for the European constitution. 
There is no question that the share of jobs and investment by US based multinationals is increasingly located overseas (see Tables 1 and 2 in this paper). Anecdotal evidence also suggests that the relocation of jobs overseas is not just confined to low-skill labor. For example, in a recent survey of firms in the computer industry, researchers found that the second most important determinant of an overseas production site was the availability and cost of skilled labor. $^{1}$ In July, 2003, the New York Times reported that IBM is thinking of accelerating the relocation of white-collar, high paying jobs to China, India, the Philippines, Russia and other countries. $^{2}$ In January 2004, the Wall Street Journal reported that IBM expects to save \$168 million dollars annually by shifting several thousand high-paying programming jobs overseas. ${ }^{3}$

In this paper, we use simple stylized facts to show that the degree of "complementarity" between US and foreign labor depends on (1) the location of foreign affiliates and (2) the level of aggregation of the data. By doing this, we are able to reconcile the arguments for "complementarity" between economic activity at home and abroad with anecdotal evidence in the popular press of factory closings and downward pressure on wages. Our data are firm level data collected by The Bureau of Economic Analysis (BEA) in Washington, D.C. on employment, wages, net-income and investment. These firms accounted for approximately 60 percent of US sales and employment in manufacturing, 70 percent of exports, and 80 percent of private $\mathrm{R}$ and $\mathrm{D}$ in manufacturing during the 1980s and 1990s (Mataloni et al, 1996). We focus primarily on trends in employment at home and abroad, separating employment in low-income countries and employment in other industrialized countries.

\footnotetext{
${ }^{1}$ See McMillan et al (1999)

${ }^{2}$ New York Times, 7/23/03
} 
We begin by describing the data and documenting the trends in key variables for US multinationals in both manufacturing and services. Between 1977 and 1999 multinational manufacturing firms shed more than 3 million jobs in the United States. Affiliates in highincome countries shed around half a million jobs while the number of jobs in affiliates in lowincome countries expanded by between half (77-99) and three quarters of a million (82-99). Real wages increased in the US based multinationals and in high-income country affiliates while they fell in low-income affiliates. In all three locations, labor's share of income fell, suggesting that wages increases failed to compensate for aggregate job losses (see Table 1).

We then report correlations between employment at home and abroad at the firm level. At the firm level, employment expansions and contractions in US multinational parents and their affiliates on average move in the same direction. This positive correlation between jobs at home and abroad suggests that foreign employment for US multinationals is complementary to domestic employment. However, these averages mask significant heterogeneity across different kinds of enterprises. For parents that hire workers in developing countries - roughly half the sample - the story is different. For these firms, there is substitution between employment at home and employment abroad. This evidence highlights the importance of differentiating between jobs in low-income countries and jobs in other industrialized countries. It is consistent with the notion that some firms do relocate activity abroad to reduce their total wage bill. Our evidence also suggests that while some jobs have been "exported abroad", this is only part of the explanation for the sharp contraction in parent employment. While three million jobs were lost in the United States, the net increase in jobs in developing countries was at most three quarters of a million, suggesting a general trend in all parts of the globe towards substituting capital for labor.

\footnotetext{
${ }^{3}$ Wall Street Journal, 1/19/04
} 
We then examine broad correlations between employment at home and abroad by aggregating the firm-level data to the industry level. This exercise is important because US firms could respond to global opportunities in ways other than through substituting employment in the US for affiliate employment elsewhere. If US firms simply close down operations, then employment at home could be replaced by employment abroad through substitution across firms. In other words, substitution can occur both within the same firm and between firms as some firms exit and their activity is taken over by affiliates of other US firms. This second kind of substitution is likely to be overlooked if researchers focus purely on within firm effects. Both Brainard and Riker (1997a, 1997b) and Desai, Foley and Hines (2004) restrict their analysis to within firm changes, which misses this possible reallocation of employment — from the US to foreign affiliates--across firms within a sector. This kind of substitution can - at least partially be captured by studying employment patterns at the industry level. Studying employment patterns at the industry level has the additional advantages of capturing patterns in the data due to entry and exit or heterogeneity due to firm size.

Our preliminary analysis suggests that some substitution did occur at the industry level. Some parents reduced employment in the US, while other US parents in the same sector increased employment abroad through the establishment and expansion of their affiliates. ${ }^{4}$ While there is broad complementarity between US and foreign jobs for many sectors, foreign employment in developing countries has replaced US employment in several highly visible industries, including computers, electronics and transportation. Moreover, the "complementarity" that does exist has, in most cases, been driven by a contraction in manufacturing employment 
both in the US and abroad. The fact that there were US jobs lost to foreign affiliates in key sectors, while at the same time there was broad complementarity in hiring (and firing) across parents and affiliates, helps to explain why economists are painting a rosy picture of globalization's impact on US labor and at the same time there is negative news coverage for declining industries.

This research is part of a larger research agenda among international and labor economists that aims to identify how globalization is affecting the jobs and lives of American workers. Many researchers who examine the links between globalization and labor markets conclude that much of the increase in inequality and falling unskilled worker wages is due to skill-biased technical change. It is frequently difficult to disentangle technical change from the effects of globalization. Related work includes research by Slaughter (2001), Rodrik (1997), and Richardson and Khripounova (1996). These authors have argued that globalization is affecting labor by increasing the elasticity of labor demand. However, Slaughter's (2001) study shows that the rising elasticity of demand for unskilled labor cannot be easily linked to different measures of globalization. Budd and Slaughter (2000) show that union wage determination in Canada is affected by changing profits in both Canada and the United States. Their work suggests that globalization does affect union wages, although they do not test for the impact on labor shares or for the impact on non-unionized workers. Rob Feenstra and Gordon Hanson have done a number of studies analyzing the effect of outsourcing on labor market outcomes; their work is reviewed in Feenstra and Hanson (2003).

\footnotetext{
${ }^{4}$ At this stage, we have only looked at these relationships within the broad headings of manufacturing and services. This leaves open the possibility that when we aggregate the two, we find broad complementarity.
} 
In Section II, we begin by outlining broad trends in employment and wages for US parent companies and their affiliates in developed and developing countries. We report these trends separately for manufacturing and services. The results document the large fall in manufacturing employment at home, and increasing affiliate employment in developing countries. The results also point to large increases in activities of US multinationals in services, with expanding employment both at home and abroad. In Section III, we report the correlations between hiring and firing at home and abroad for US multinationals. We then turn to the industry-level patterns, showing the relationship between employment at home and abroad for both manufacturing and services. Section IV concludes, and points to directions for further research.

\section{Broad Trends in US Multinational Activity: the BEA Data}

We analyze the firm-level surveys on US direct investment abroad, collected each year by the Bureau of Economic Analysis (BEA) of the U.S. Department of Commerce. The BEA collects confidential data on the activities of US based multinationals defined as the combination of a single US entity that has made the direct investment, called the parent, and at least one foreign business enterprise called the foreign affiliate. We use the data collected on majorityowned non-bank foreign affiliates and non-bank US parents for the benchmark years between 1977 and 1999. The benchmark years are 1977, 1982, 1989, 1994 and 1999 and include more comprehensive information than the annual surveys. To our knowledge, very little work has been done with the firm-level data using the entire length of the time series from 1977 through 1999.

Creating a panel using the benchmark years of the BEA survey data is a nontrivial task. First, not all firms are required to report to the BEA and reporting requirements vary across 
years. Second, because we are interested in understanding what is happening at the industry level, we must consider the implications of the changes to the Standard Industrial Classification (SIC) codes in 1972 and 1987 and the switch from SIC codes to the North American Industrial Classification System (NAICS) codes in 1997. Third, because the BEA parent identification codes changed between 1977 and 1982, we had to create a bridge linking the 1977 parents to the 1982 parents $^{5}$. And finally, the fact that parents are allowed to consolidate information for several affiliates in one country on a single form calls for special care in the aggregation and interpretation of affiliate level data.

All foreign affiliates with sales, assets or net income in excess of a certain amount in absolute value must report to the BEA. This amount was $\$ .5$ million dollars in $1977, \$ 3$ million dollars in 1982, 1989 and 1994 and jumped to \$7 million dollars in 1999. In addition, a new reporting requirement was imposed on parents in 1999. Parents whose sales, assets or net income exceeded \$100 million (in absolute value) were required to provide more extensive information than parents whose sales, assets or net income fell below $\$ 100$ million ${ }^{6}$. To determine whether the changes in reporting requirements biased our sample toward small firms in the early years, we imposed a double filter on the data using the uniform cutoff for affiliates of $\$ 5.59$ million 1982 US dollars and \$79.87 1982 US dollars for parents. As it turns out, the reporting requirements were large enough that imposing the filter on the data makes little difference. Therefore, we use all of the available data.

\footnotetext{
${ }^{5}$ Prior to our arrival, a bridge had been created but it was incomplete, only linking around $25 \%$ of the parents from 1977 to parents in 1982. With our bridge based on employee identification numbers, we are able to link more than $50 \%$ of the parents from 1977 to parents in 1982.

${ }^{6}$ Parents who do not meet this cutoff but who have affiliates that meet the $\$ 7$ million cutoff are still required to provide extensive information for affiliates.
} 
To document what has happened within industries in manufacturing over time, we created a concordance that allows us to assign SIC codes to NAICS codes. This was necessary because in 1999, the BEA collected data on NAICS codes and not SIC codes. We chose to convert SIC codes to NAICS codes on the grounds that the NAICS codes more accurately describe production processes. The 1977 and 1982 benchmark years are based on the 1972 SIC codes. The 1989 and 1994 benchmark years are based on the 1987 SIC codes. The 1999 benchmark data are based on the 1997 NAICS codes. In addition to the fact that the industry codes are not directly comparable across all benchmark years, the BEA industry codes have been slightly modified to reflect that fact the these are enterprise data and are called respectively SICISI and NAICS-ISI. Working with these codes, we created a program (available upon request) that assigns the SIC-ISI codes for the years 1977-1994 to NAICS-ISI codes.

Linking parents from 1977 to the remaining benchmark years proved relatively straightforward. This is because in addition to a parent identification code created by the BEA (which changed between 1977 and 1982), each parent has an employee identification number (EIN) assigned to it by the Internal Revenue Service which did not change during the period 1977-1999. Using the EIN number plus the country in which the affiliate operates, we are also able to track parent/affiliate pairs over time.

While the number of US parents included in the BEA sample may appear small (see Table 1), these enterprises accounted for the majority of economic activity in US manufacturing during the entire sample period. Between 1982 and 1999, sales by these enterprises accounted 
for approximately 60 percent of total manufacturing sales in the United States. ${ }^{7}$ In 1994, these enterprises accounted for 66 percent of all exports of goods, and nearly 60 percent of employment in manufacturing. These enterprises also account for most of US research and development expenditures: in 1994, the US parents included in the BEA sample accounted for 82 percent of total US research and development expenditures.

The variables we use are reported to the BEA on the basis of the fiscal year. General trends in employment weighted averages are reported in Table 1 for manufacturing and in Table 2 for services. The numbers in Table 2 include all firms classified in services under the SIC classification prior to 1997 and under the NAICS system post-1997. Because the NAICS system classifies some industries as services that were not previously classified as services, the employment numbers are slightly exaggerated. However, when we restrict our analysis of services to only those sub-categories that can be exactly matched across years, we get nearly identical trends.

Table 1 shows that between 1977 and 1999 multinational manufacturing firms shed more than 3 million jobs in the United States ${ }^{89}$. In addition, Table 1 also documents that labor's share of income in the US has fallen from ninety to seventy five percent. The loss of jobs in the U.S. has been mirrored by job reductions in affiliates in developed countries. In developed country affiliates, employment fell by roughly half a million. Labor's share and wages in the developed countries follow the US labor share and wages although in the developed country affiliates,

\footnotetext{
${ }^{7}$ See the December 1996 issue of the Survey of Current Business, "Operations of US Multinational Companies: Preliminary Results from the 1994 Benchmark Survey", by Mataloni and Fahim-Nader, as well as the authors' own calculations.

${ }^{8}$ Our sample consists of all parents that were ever classified in manufacturing and their manufacturing affiliates.
} 
labor's share is substantially lower as are real wages. These job losses have been only partially offset by an increase in the number of jobs in developing countries, where the number of jobs increased by half a million between 1977 and 1999 and by three quarters of a million between 1982 and 1999. In developing countries, labor's share also fell. Unlike in the developed countries, real wages paid by US based multinationals to employees in their developing country affiliates has actually fallen. The evidence for the US parents is in line with the aggregate trends in the U.S. manufacturing sector. According to the NBER Manufacturing Productivity Database, labor's share in value-added declined from .53 to .31 - roughly $50 \%$ - over the period 1958 to 1996. Over the period of time for which the two datasets overlap, real wages, employment and labor's share in income all move in the same direction - down.

There has been a substantial shift in activity from developed to developing country affiliates. Affiliate employment as a share of total employment globally for US multinationals increased from 28 percent in 1977 to 35 percent in 1999. The increase was almost entirely driven by a doubling of affiliate employment shares in developing countries, from 8 to 15 percent. Affiliate employment in developed countries, as a share of total worldwide employment, remained roughly constant over the entire period at around 20 percent. Total affiliate share of employment, employee compensation, and investment in the firms' total has increased by 26,27 and 12 percent respectively. This increase in overseas activity has been largely reserved for developing countries where the respective increases are 78, 89 and 45 percent respectively.

\footnotetext{
${ }^{9}$ Our numbers differ from numbers published by the BEA for several reasons. Our data do not include estimated data, our variables are weighted by parent employment when applicable and our sample takes into account the fact that some manufacturing firms have been reclassified under wholesale trade.
} 
The increase in developing country activity has been accompanied by a reduction in labor's share at the parent level of 18 percent. Labor's share has also fallen overseas: by around 27 percent in developed country affiliates and 39 percent in developing country affiliates. Although part of the reduction in labor's share in the parent and in developed country affiliates is driven by reductions in employment, the reduction in labor's share in developing countries is not: employment in developing country affiliates increased by 46 percent. Though not shown in the table, our data indicate that there was a 120 percent increase in the number of non-production workers hired in developing countries.

The contraction in domestic jobs in the manufacturing sector has been more than offset by job creation in the services sector. Table 2 shows that between 1977 and 1999, employment by US parents increased by more than 4 million or 802 percent. Expansion at home has been more than matched by expansion abroad. In developed country affiliates employment increased from 73 thousand in 1977 to 1.2 million in 1999 and in developing country affiliates employment went from 24 thousand in 1977 to 363 thousand in 1999. While the share of affiliate activity still counts for less than the share of affiliate activity in manufacturing, it has grown much more rapidly in services than in manufacturing. Affiliate share of employment, employee compensation, and investment in the firms' total has risen by 63, 62 and 66 percent respectively. Except for affiliate share of compensation, this increase in overseas activity has been fairly evenly spread between developed and developing country affiliates. This increase in developing country activity has been accompanied by a reduction in labor's share at the parent level of 11 percent. Unlike in manufacturing, labor's share overseas has remained relatively constant. 
Tables 1 and 2 suggest that job losses in the manufacturing sector may have been offset by employment increases in the service sector. However, it is important to keep in mind that throughout the period 1977-1999, real compensation per worker in the service sector amounts to little more than half of real compensation per worker in the manufacturing sector. This may be partly a reflection of the change in the mix of workers in the US manufacturing sector-- if unskilled US workers have been replaced by unskilled foreign workers then the average wage in the US manufacturing sector reflects the wages of skilled workers. However, the fact that this differential existed even in 1977 before the big contraction in US manufacturing suggests that this is not the only reason for the difference. Since data on the composition of employment for US parents is less detailed than the information on the skill mix of foreign affiliates, it is difficult to reach any strong conclusions on this point. What tables 1 and 2 do show is that employment in manufacturing has shifted to services, and that average compensation in services was well below compensation in manufacturing even at the start of the sample period.

\section{Employment at Home and Abroad}

This section discusses broad trends in the pattern of employment changes in US parents and their affiliates. We restrict our analysis to the period 1982 to 1999 for comparability with the work by Brainard and Riker (1997a, 1997b) and Desai et al (2005) who used these same data beginning in $1982 .{ }^{10}$ We begin by reporting activities within the same enterprise over time. To test whether US parents are substituting US employment with affiliate employment, we created a series of employment offsets at the firm level. Figures 1through 3 track the same parent and its affiliates over time, documenting the extent of hiring and firing within the same parent and its

\footnotetext{
${ }^{10}$ If we extend the period to 1977 , and redo the results for 1977 to 1999 , the results look very similar.
} 
affiliates $^{11}$. We begin with all affiliates and all parents, for the entire period 1982 through 1999 and then separate the sample to examine employment changes in high and low-income countries. In all three figures, the horizontal axis represents changes in parent employment between 1982 and 1999 while the vertical axis represents changes in affiliate employment over this same period. Points in the upper right hand side quadrant and lower left hand side quadrant represent complementarity: firms expanding(contracting) at home are also expanding(contracting) abroad. Critics of globalization have focused on the upper left hand side quadrant where a contraction at home corresponds with an expansion abroad.

Figure 1 shows that for all affiliates employment abroad and employment at home are complementary. Most of the firm activity is on the diagonal quadrants in Figure 1 - this is confirmed by the positively sloped regression line. The cluster of points around zero suggests that for the majority of firms, employment changes both at home and abroad have been tiny. Figure 2 plots the relationship between employment at home and employment in high-income affiliates. The story is similar to that found in Figure 1 with the complementarity slightly more pronounced. The employment offsets for the US parent and its developing country affiliates shown in Figure 3 are somewhat different, however. In this case, the majority of firms lie in the off-diagonal quadrants as confirmed by the downward sloping regression line. However, the fact that the line is practically flat (albeit downward sloping) suggests that the relationship between employment in developing countries and employment at home may not be that important.

\footnotetext{
${ }^{11}$ We need to be somewhat careful about calling these changes in employment hires and fires as some of the activity might simply reflect acquisitions and spin-offs. However, at least in the aggregate, since most sales of US multinationals are to other US multinationals, the firms would still remain in our database even if they were acquired by another firm. Therefore, it is reasonable to assume that the overall "contraction" in the manufacturing sector represents a loss of US jobs.
} 
Figures 1 to 3 report trends in employment within the same enterprise. However, it is possible that much of the substitution away from US employment towards employment abroad has occurred between enterprises. Some firms may have contracted US employment while other firms expanded affiliate employment. These possibilities cannot be captured by tracking the same enterprise over time. By tracking within firm changes in employment, we also miss entry and exit. This is potentially very important because we miss large firms that may have shut down altogether. To the extent that this happens in conjunction with small increases in employment at home and abroad in other firms we would see complementarity in the firm level results and substitution at the industry level.

Finally, the data in Figures 1 through 3 suggest that it is important to distinguish between "small" and "large" firms. The positive correlations between employment at home and abroad could be driven by the small changes that are relatively symmetrically distributed around zero. Since our focus is employment, we would like to give extra weight to the firms that hire relatively more workers. An informal way of doing this is aggregating up to the industry level. The small changes around zero will disappear and we will be left with the net effect of employment changes in the large firms which are not so symmetrically distributed around zero. To address all of these possibilities, we turn now to trends in employment at the aggregate industry level.

Figure 4 reports employment offsets at the 3-digit level for the manufacturing sector. Changes in parent (US) total employment are indicated by the horizontal axis and changes in affiliate total employment are indicated by the vertical axis. A point in the upper right-hand quadrant indicates expansion both at home and abroad. A point in the lower left-hand side 
quadrant indicates contraction at home and abroad. Substitution occurs if data points are either in the upper left-hand quadrant (indicating contraction at home and expansion in affiliate employment) or in the lower right-hand quadrant (indicating expansion at home and contraction abroad). Most US critics of globalization center on supposed activity in the upper left-hand quadrant, which would indicate expansion of affiliate employment and contraction of employment in the US; so-called substitution of foreign for US jobs. As Figure 4 shows, most of the activity of US manufacturing multinational enterprises has taken place in the lower left-hand quadrant, indicating employment contraction both at home and abroad.

Figures 5 and 6 separate changes in employment from 1982 to 1999 based on the location of the parent's affiliates. Figure 5 reports employment offsets at the 3 digit level for developed country affiliates and parents; Figure 6 reports the same trends for developing country affiliates. The trends are similar across Figures 4 and 5 - employment in high-income affiliates and parent employment are complementary but that relationship is driven by the contraction in manufacturing. However, Figure 6 reveals that employment in low-income affiliates substitutes for employment in the US. Moreover, the downward sloping regression line appears to be driven by contraction in two key sectors: computers and electronics.

Why are the firm and industry offsets so different? We mentioned three possibilities that deserve further elaboration: entry and exit, firm size and across firm substitution. Roughly one quarter of the job losses in our sample are due to firm "deaths" and not a sale or acquisition. Entrants account for a relatively small number of jobs. We do not pick these firms up when we do the within firm analysis. Additionally, small firms (with less than 15,000 employees) account for $75 \%$ of the firms in our sample but only $24 \%$ of total employment. Small firms tend to have 
affiliates only in high-income countries while the large firms tend to have affiliates in both high and low-income countries. Since the small firms are more numerous, they cloud somewhat the story in the within firm offsets.

While the stylized facts reported in this paper are useful for explaining why opinions on the outsourcing of US jobs are so different, these facts don't tell us enough about the underlying mechanisms at work. The fact that substitution occurs only between US jobs and jobs in lowwage countries suggests that labor costs are important. An alternative explanation could be based on differential demand shocks. Individuals in countries at the low end of the income distribution may exhibit different preferences than those in high-income countries and/or US multinationals may be better at marketing their products abroad than at home. Yet the explanation for substitution of US jobs most popular in the US press is a story about labor costs: labor is relatively cheaper in developing countries, therefore profit seeking US multinationals fire expensive US workers and hire workers in low-income countries. To properly identify the causal mechanisms at work, we are developing a conceptual framework that incorporates both of these possibilities.

Finally, we wish to emphasize the aggregate employment shift towards services. We saw in Tables 1 and 2 that the contraction in manufacturing employment by US parents was largely offset by increasing service sector employment. One recent concern is that the kind of employment substitution we observe between some developing country affiliates and the US parent is now occurring in the service sector as well. Though not reported here, our data indicate that -- at least for the period 1977 to 1999--this was not the case. Unlike the employment offsets for manufacturing, where nearly all the data points are in the lower left-hand side quadrant 
(indicating contraction at home and abroad), the offsets indicate that in services ${ }^{12}$ all the activity is in the upper right-hand side quadrant. Although the recent concerns regarding offshoring or outsourcing of service sector employment may be valid, the aggregate trends for the period between 1977 and 1999 in the BEA services data do not support such claims.

\section{Concluding Comments}

This paper outlines broad trends in US multinational employment at home and abroad. Over the period 1977 to 1999 multinational manufacturing firms have shed more than 3 million jobs in the United States. During this period, labor's share of income has fallen and real wages have increased. The loss of jobs in the U.S. has been partially offset by an increase in the number of jobs in developing countries. Even overseas, as the number of jobs has increased, real wages and labor's share of income have declined. These labor market outcomes have been accompanied by a substantial shift in the operations of US multinationals abroad.

We then examine the relationship between employment changes at home and abroad for US multinational firms, presenting evidence on trends in both manufacturing and services. We also report broad trends in employment patterns both at the US parent and at its affiliates. We document that whether employment changes in the US parent and its affiliates tend to move in the same direction depends upon whether the jobs abroad are in low-income or high-income countries. Jobs in low-income affiliates are substitutes for US jobs while jobs in high-income affiliates are complementary with US jobs. Thus, the sharp contraction in US manufacturing jobs between 1977 (1982) and 1999 was accompanied by a contraction in jobs in high-income

\footnotetext{
${ }^{12}$ These are not all of the data used in Table 2 but only the data (including business services) that could be exactly
} 
affiliates. While we focused primarily on the manufacturing sector in this paper, we do find evidence that in the service sector there has been job expansion both for the US parents and its foreign affiliates in high and low-income countries.

The substitution of jobs in low-income countries for jobs in the US is even stronger at the industry level. One reason is because many of the US enterprises that previously manufactured in the United States are no longer active, indicating that it is necessary to analyze behavior between, rather than within, enterprises. Another reason is because much of the job relocation to developing countries has occurred within large enterprises, and industry-level results give more weight to large enterprises. At the industry level, there has been significant job relocation in a number of key areas: computers, electronics and transportation. At the industry level, employment offsets for the US parent and its developing country affiliates indicate that employment is not complementary: expansion abroad is accompanied by contraction in the United States.

The kinds of employment shifts documented in this paper are natural in light of the differences in labor costs in the US and in its developing country affiliates. In addition, the tables and graphs also make clear that employment in manufacturing has been contracting almost everywhere, presumably due to technological change which makes it possible to substitute capital for labor. Our ultimate goal--which is beyond the scope of this paper--is to estimate the extent to which technological change versus global cost pressures can explain aggregate employment contraction and rising capital intensity. It is also important to remember that 
substitution of foreign jobs for US jobs may have saved some US jobs; some firms were able to stay in business because they were able to substitute foreign for US labor. 


\section{Bibliography}

Abowd, John and Thomas Lemieux, "The Effects of Product Market Competition on Collective

Bargaining Agreements: The Case of Foreign Competition in Canada", Quarterly Journal of Economics, 1993, 108(4), 983-1014.

Aitken, Brian, Ann Harrison and Robert Lipsey, "Wages and Foreign Ownership: A

Comparative Study of Mexico, Venezuela, and the United States", Journal of International

Economics, May 1996, Vol. 40, Nos. 3/4, pages 345-371.

Amiti, Mary and Shang-Jin Wei, "International Service Outsourcing, Productivity and Employment: Evidence from the US”, IMF Working Paper WP/05/xx, September 2005.

Blanchard, Olivier, “The Medium Term”, Brookings Papers on Economic Activity, 2:1997.

Brainard, Lael and David Riker, "US Multinationals and Competition from Low Wage Countries", NBER Working Paper 5959, March 1997a.

Brainard, Lael and David Riker, “Are US Multinationals Exporting US Jobs?”, NBER Working Paper 5958, March 1997b.

Budd, John W. And Matthew Slaughter, “Are Profits Shared Across Borders? Evidence on International Rent Sharing”, NBER Working Paper Number 8014, November 2000.

Currie, Janet and Ann Harrison, "Sharing the Costs: the impact of trade reform on capital and labor in Morocco", Journal of Labor Economics, Vol. 15, No. 3, 1997. 
Desai, Mehir, Fritz Foley and James Hines, "Foreign Direct Investment and Domestic Economic Activity," Harvard Business School Working Paper, November 2004

Feenstra, Robert C., and Gordon Hanson, “Globalization, Outsourcing, and Wage Inequality,” AER Papers and Proceedings, 297-322, 1996.

Feenstra and Hanson (2003), "Global Production Sharing and Rising Inequality: A Survey of Trade and Wages", Forthcoming, Handbook of International Economics.

Hanson, Gordon, and Ann Harrison, "Who Gains from Trade Reform? Some Remaining Puzzles", Journal of Development Economics, No. 59: 125-154, 1999.

Harrison, Ann, "Has Globalization Eroded Labor's Share? Evidence from Cross-country Data", manuscript in progress, 2003.

Kennan, John, "Simultaneous Equations Bias in Disaggregated Econometric Models", Review of Economic Studies, No. 56: 151-156, 1989.

Kanbur, Ravi, "Economic Policy, Distribution and Poverty: The Nature of Disagreements", World Development, 2001.

Mataloni, Raymond J. Jr. “U.S. Mulitnational Companies: Operations in 1997”, Survey of Current Business, July 1999

Mataloni, Raymond J. Jr. and Mahnaz Fahim-Nader, "Operations of U.S. Multinational Companies: 
Preliminary Results From the 1994 Benchmark Survey”, Survey of Current Business, December 1996

McMillan, Margaret, Selina Pandolfi and Lynn Salinger, "Promoting Labor Intensive Exports in Developing Countries: Evidence from the Textile and Electronics Industries", Harvard Center for International Development, CAER working paper no. 22, May 1999.

Poterba, James, "Recent Developments in Corporate Profitability: Patterns and Explanations", Mimeo, March 1997.

Rama, Martin and Raquel Artecona, "A Database of Labor Market Indicators Across Countries”, unpublished manuscript, Washington, DC:The World Bank, June 25, 2002

Richardson, J. David and Elena B. Khripounova, "U.S. Labor Market Power and Linkages to International Trade: Indentifying Suspects and Measures", Draft for U.S. Department of Labor, 1998.

Rodrik, Dani, Has Globalization Gone Too Far?, Institute for International Economics, Washington, D.C., 1997.

Slaughter, Matthew, "Production transfer within multinational enterprises and American wages", Journal of International Economics, 50 (2), 449-472, April, 2000.

Slaughter, Matthew, "International Trade and Labor-Demand Elasticities”, Journal of International Economics, 54(1), 27-56, June, 2001. 


\begin{tabular}{|c|c|c|c|c|c|c|c|}
\hline$\underline{V a r i a b l e}$ & 1977 & 1982 & 1989 & 1994 & 1999 & $\frac{\% \text { Change }}{\underline{77-99}}$ & $\frac{\text { \% Change }}{\underline{82-99}}$ \\
\hline Number of Parents & 1746 & 1154 & 1211 & 1199 & 878 & $-98.86 \%$ & $-31.44 \%$ \\
\hline Number of Countries in which Parents Have Affiliates & 21.19 & 20.61 & 20.35 & 21.54 & 19.78 & $-7.14 \%$ & $-4.17 \%$ \\
\hline Developed Countries & 12.25 & 12.54 & 13.47 & 13.41 & 11.33 & $-8.13 \%$ & $-10.70 \%$ \\
\hline Developing Countries & 8.80 & 7.98 & 6.81 & 8.09 & 8.45 & $-4.11 \%$ & $5.63 \%$ \\
\hline Affiliate Share of Jobs & $28.33 \%$ & $26.57 \%$ & $31.43 \%$ & $33.91 \%$ & $35.62 \%$ & $20.46 \%$ & $25.40 \%$ \\
\hline Developed Country Affiliate Share of Jobs & $20.09 \%$ & $18.43 \%$ & $21.59 \%$ & $22.78 \%$ & $20.98 \%$ & $4.24 \%$ & $12.14 \%$ \\
\hline Developing Country Affiliate Share of Jobs & $8.22 \%$ & $8.11 \%$ & $9.84 \%$ & $11.08 \%$ & $14.64 \%$ & $43.88 \%$ & $44.62 \%$ \\
\hline Affiliate Share of Compensation & $18.97 \%$ & $17.56 \%$ & $22.96 \%$ & $25.61 \%$ & $24.17 \%$ & $21.52 \%$ & $27.36 \%$ \\
\hline Developed Country Affiliate Share of Compensation & $16.35 \%$ & $14.44 \%$ & $20.15 \%$ & $21.95 \%$ & $19.27 \%$ & $15.16 \%$ & $25.09 \%$ \\
\hline Developing Country Affiliate Share of Compensation & $2.59 \%$ & $3.09 \%$ & $2.80 \%$ & $3.63 \%$ & $4.89 \%$ & $47.05 \%$ & $36.80 \%$ \\
\hline Affiliate Share of Total Investment & $25.99 \%$ & $23.29 \%$ & $25.14 \%$ & $29.08 \%$ & $29.10 \%$ & $10.66 \%$ & $19.96 \%$ \\
\hline Developed Country Affiliate Share of Investment & $20.12 \%$ & $17.29 \%$ & $20.95 \%$ & $23.72 \%$ & $20.88 \%$ & $3.63 \%$ & $17.21 \%$ \\
\hline Developing Country Affiliate Share of Investment & $5.67 \%$ & $5.80 \%$ & $4.17 \%$ & $5.33 \%$ & $8.22 \%$ & $30.97 \%$ & $29.36 \%$ \\
\hline \multicolumn{8}{|l|}{ Parents } \\
\hline Total Employment & 11017 & 9771 & 9137 & 6893 & 7181 & $-53.42 \%$ & $-36.07 \%$ \\
\hline Real Total Compensation (per worker) & 31.34 & 31.82 & 33.25 & 36.67 & 37.87 & $17.24 \%$ & $15.97 \%$ \\
\hline Labor's Share & 0.96 & 0.91 & 0.84 & 0.86 & 0.79 & $-21.54 \%$ & $-15.03 \%$ \\
\hline \multicolumn{8}{|l|}{ Developed Country Affiliates: All } \\
\hline Total Employment & 3089 & 2753 & 2876 & 2376 & 2531 & $-22.05 \%$ & $-8.78 \%$ \\
\hline Real Total Compensation (per worker) & 21 & 21 & 27 & 31 & 27 & $20.32 \%$ & $20.05 \%$ \\
\hline Labor's Share & 0.61 & 0.59 & 0.57 & 0.57 & 0.30 & $-101.76 \%$ & $-95.15 \%$ \\
\hline \multicolumn{8}{|l|}{ Developing Country Affiliates: All } \\
\hline Total Employment & 1263 & 1079 & 1311 & 1156 & 1766 & $28.48 \%$ & $38.91 \%$ \\
\hline Real Total Compensation (per worker) & 11 & 10 & 9 & 9 & 8 & $-38.25 \%$ & $-19.93 \%$ \\
\hline Labor's Share & 1.09 & 1.18 & 0.61 & 0.60 & 0.67 & $-62.86 \%$ & $-76.96 \%$ \\
\hline $\begin{array}{l}\text { Source: Bureau of Economic Analysis. Note: Data is for } \\
\text { labor's share of income, positive employment, and non-zer } \\
\text { Weighted by employment shares, where applicable. Real } \\
\text { income and real total assets are in ' } 000,000 \text { of } 82-84 \text { U.S. } \\
\text { Variability in countries of affiliates is defined as the total nu } \\
\text { benchmark survey and the present one. }\end{array}$ & $\begin{array}{l}\text { duction em } \\
\text { s, real ben } \\
\text { s. Employ } \\
\text { of countrie }\end{array}$ & $\begin{array}{l}\text { loyment. I } \\
\text { its, and re } \\
\text { lent figure } \\
\text { in which t }\end{array}$ & $\begin{array}{l}\text { ir manufac } \\
\text { totiple affilia } \\
\text { totamp in '000. } \\
\text { parent ad }\end{array}$ & $\begin{array}{l}\text { es in one c } \\
\text { nsation ar } \\
\text { Return on } \\
\text { ed or drop }\end{array}$ & $\begin{array}{l}\text { untry are tr } \\
\text { in ' } 000 \text { of } 8 \\
\text { apital is net } \\
\text { ed an affilia }\end{array}$ & $\begin{array}{l}\text { nissing obse } \\
\text { ated as one } \\
\text {-84 U.S. doll } \\
\text { ncome over t } \\
\text { e between th }\end{array}$ & $\begin{array}{l}\text { ations for } \\
\text { iliate. } \\
\text { s; real net } \\
\text { al assets. } \\
\text { previous }\end{array}$ \\
\hline
\end{tabular}


Table 2: Trends of U.S. Multinationals in Services 1977- 1999

\section{Variable \\ Number of Parents \\ Developed Countries \\ Developing Countries \\ Affiliate Share of Jobs}

Number of Countries in which Parents Have Affiliates

Developed Country Affiliate Share of Jobs

Developing Country Affiliate Share of Jobs

\section{Affiliate Share of Compensation}

Developed Country Affiliate Share of Compensation

Developing Country Affiliate Share of Compensation

\section{Affiliate Share of Total Investment}

Developed Country Affiliate Share of Investment

Developing Country Affiliate Share of Investment

\section{Parents}

Total Employment

Real Wages (per worker)

Labor's Share

Developed Country Affiliates: All

Total Employment

Real Wages (per worker)

Labor's Share

\section{Developing Country Affiliates: All}

Total Employment

Real Wages (per worker)

Labor's Share

\begin{tabular}{r}
1977 \\
\hline 58 \\
6.74 \\
5.19 \\
1.56 \\
$15.43 \%$ \\
$11.67 \%$ \\
$3.76 \%$ \\
$13.41 \%$ \\
$11.20 \%$ \\
$2.21 \%$ \\
$13.97 \%$ \\
$11.88 \%$ \\
$2.09 \%$
\end{tabular}

\section{$\underline{1982}$}

76
4.12

3.10

1.02

$9.21 \%$

$7.09 \%$

$2.12 \%$

$7.25 \%$

$6.06 \%$

$1.19 \%$

$6.76 \%$

$5.79 \%$

$0.96 \%$

$\begin{array}{rr}867 & 1377 \\ 15.94 & 17.71\end{array}$

$88.00 \%$

$85.70 \%$

\section{$\underline{1989}$}

112

4.92

4.27

0.65

$16.93 \%$

$15.36 \%$

$1.57 \%$

$14.99 \%$

$14.45 \%$

$0.54 \%$

$17.65 \%$

$17.06 \%$

$0.59 \%$
$17.30 \%$

$16.38 \%$

$20.15 \%$

1994

133

6.97

5.64

1.33

$19.13 \%$

$16.22 \%$

$2.91 \%$

$0.92 \%$

$21.60 \%$

$1.45 \%$

\section{8}

1658
17.03

1999
242
11.62

11.62

7.61

3.94

$25.09 \%$

$19.41 \%$

$5.67 \%$

$21.75 \%$

$19.29 \%$

$2.46 \%$

$23.17 \%$

$19.47 \%$

$3.70 \%$

$90.68 \%$

\section{5}

20.78

$81.24 \%$

\begin{tabular}{r} 
\% Change \\
\hline$\underline{77-99}$ \\
$317.24 \%$ \\
$72.31 \%$ \\
$46.66 \%$ \\
$153.04 \%$ \\
$62.59 \%$ \\
$66.30 \%$ \\
$50.86 \%$ \\
$62.20 \%$ \\
$72.23 \%$ \\
$11.26 \%$ \\
$65.93 \%$ \\
$63.86 \%$ \\
$77.35 \%$
\end{tabular}

\% Change 82-99 $218.42 \%$ $182.10 \%$ $145.72 \%$ $284.93 \%$ $172.39 \%$ $173.65 \%$ $167.86 \%$ $200.04 \%$ $218.23 \%$ $107.00 \%$ $242.99 \%$ $236.02 \%$ $284.04 \%$

$801.93 \% \quad 453.30 \%$ $23.74 \% \quad 30.36 \%$

$-11.17 \% \quad-7.68 \%$

\begin{tabular}{rrrrrrr||}
73 & 68 & 255 & 333 & 1243 & $1593.31 \%$ & $1734.97 \%$ \\
13.28 & 15.05 & 13.88 & 14.45 & 13.86 & $4.37 \%$ & $-7.91 \%$ \\
$75.93 \%$ & $45.66 \%$ & $82.20 \%$ & $72.93 \%$ & $75.48 \%$ & $-0.60 \%$ & $65.30 \%$ \\
24 & 20 & 26 & 60 & 363 & $1436.03 \%$ & $1696.20 \%$ \\
7.43 & 9.03 & 5.38 & 4.69 & 4.45 & $-40.11 \%$ & $-50.72 \%$ \\
$88.58 \%$ & $94.40 \%$ & $84.72 \%$ & $90.09 \%$ & $84.79 \%$ & $-4.28 \%$ & $-10.17 \%$
\end{tabular}

Source: Bureau of Economic Analysis. Note: Data is for parents and affiliates with non-missing observations for labor's share of income and positive employment. Multiple affiliates in one country are treated as one affiliate. Excluding firms in the top and bottom $1 \%$ on the basis of labor shares and return to capital. Weighted by employment shares, where applicable. Real wages are in '000 of 82-84 U.S. dollars. Employment figures are in ' 000. 



\section{Figure 1: All Affiliates}

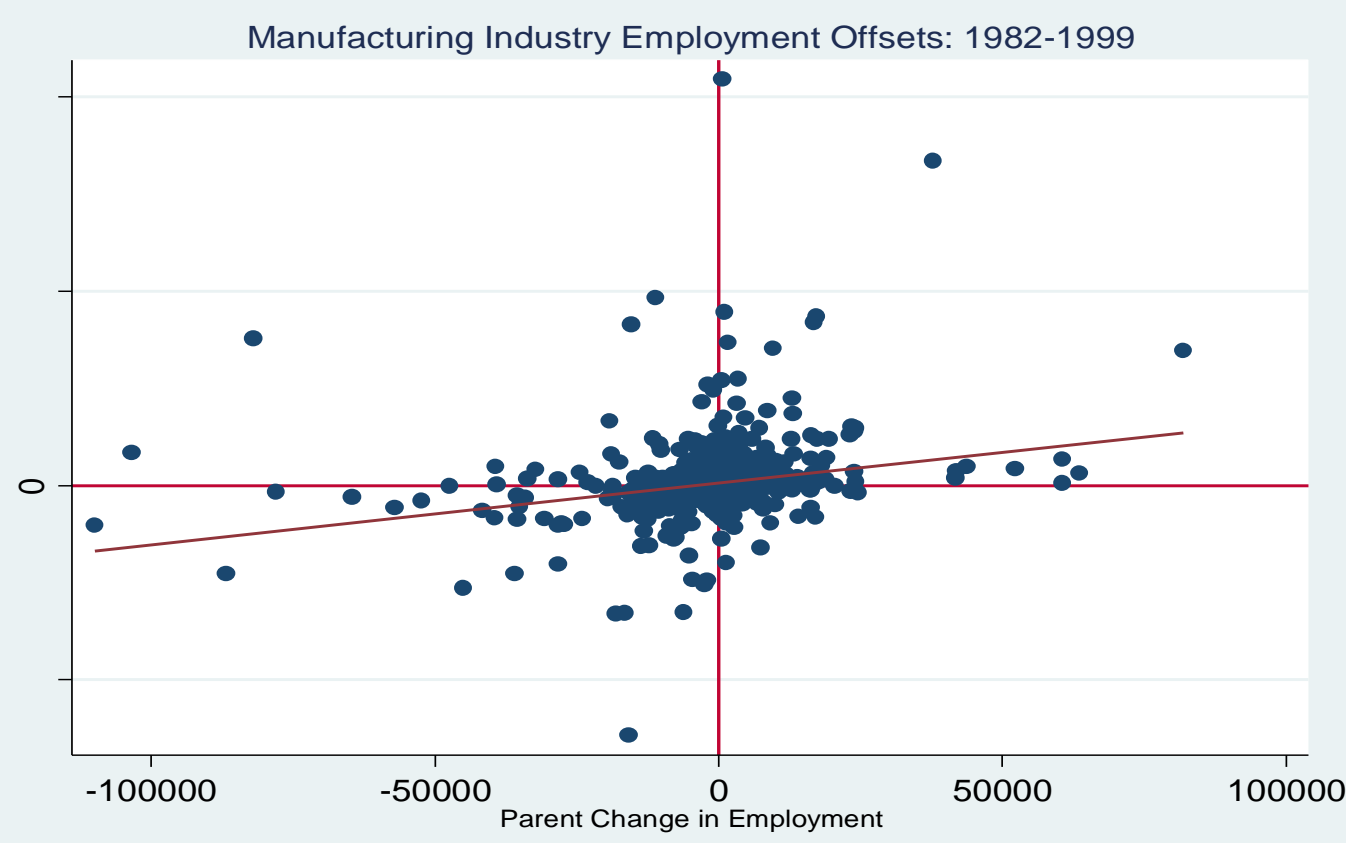

Source: Author's calculations based on BEA's outward FDI data 


\section{Figure 2: High Income Affiliates}

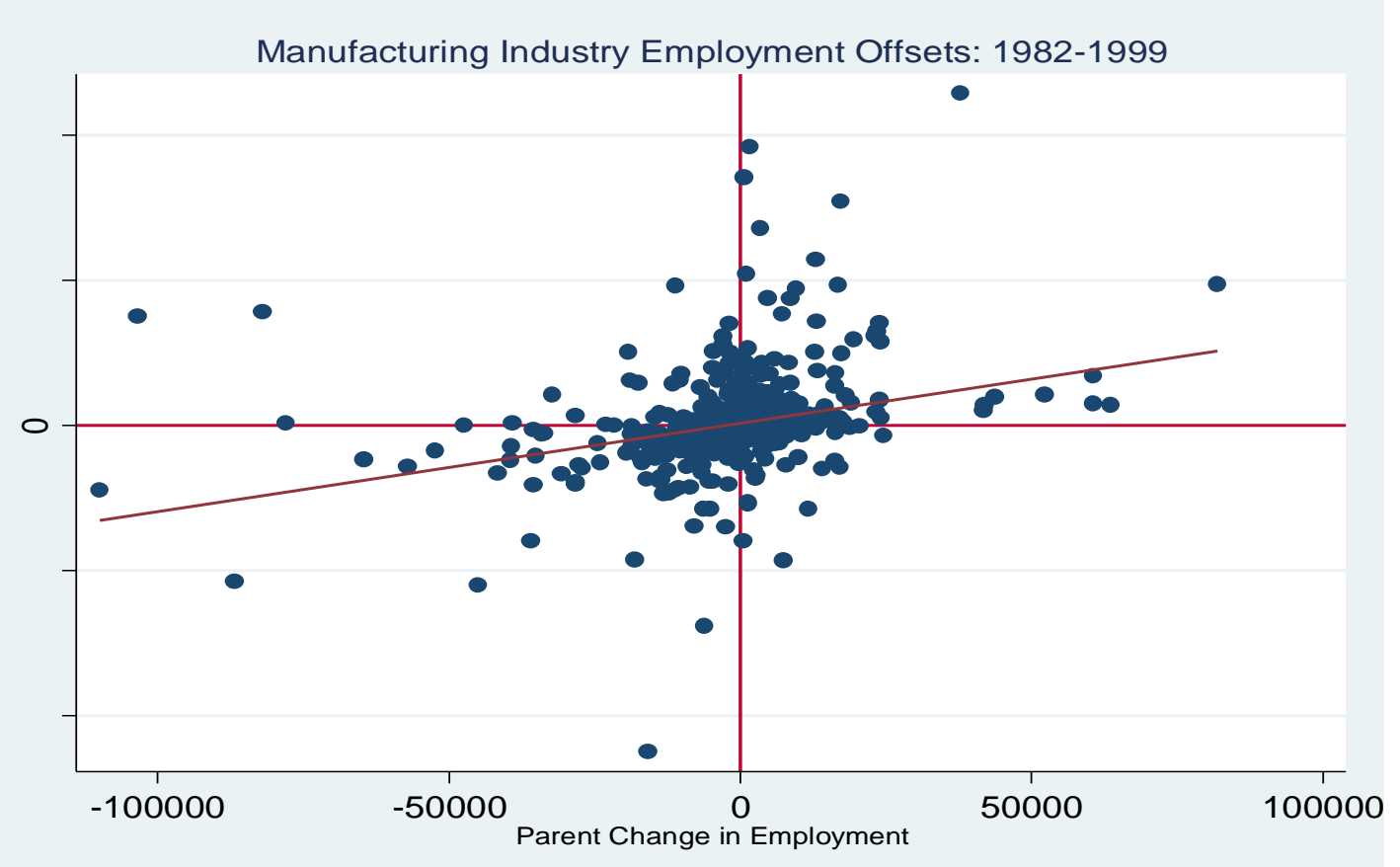

Source: Author's calculations based on BEA's outward FDI data 


\section{Figure 3: Middle/Low Income Affiliates}

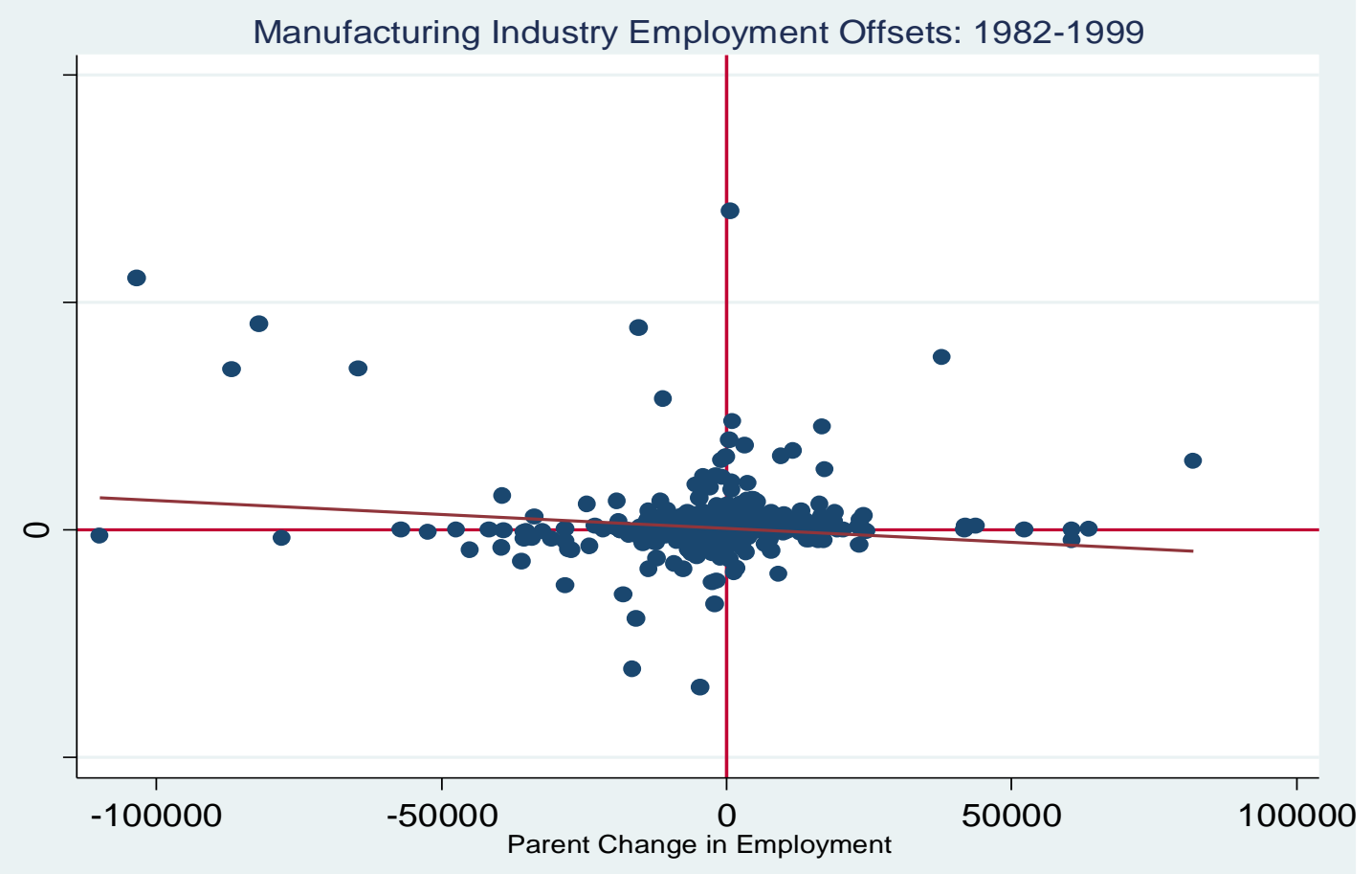

Source: Author's calculations based on BEA's outward FDI data 


\section{Figure 4: All Affiliates}

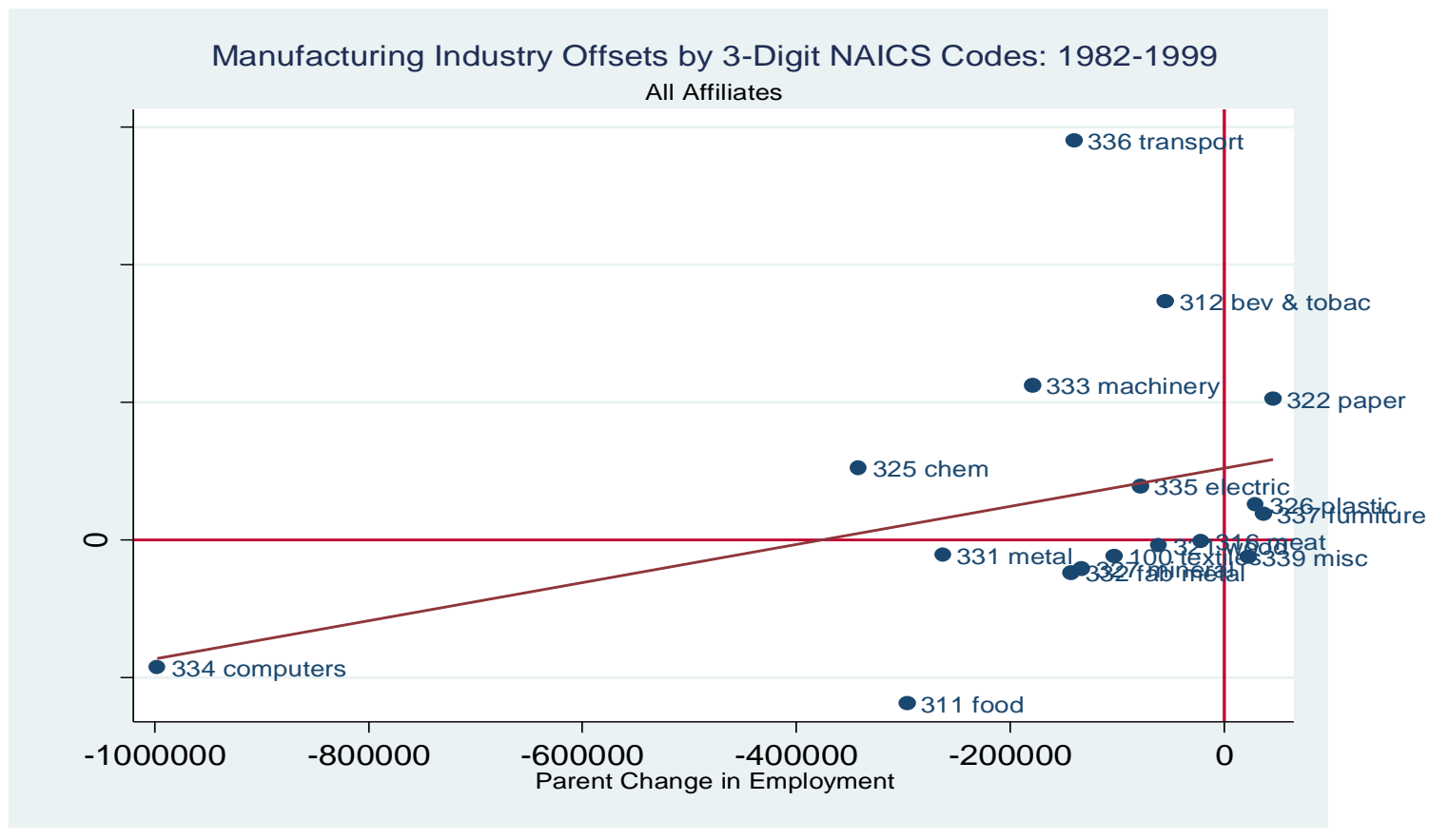

Source: Author's calculations based on BEA's outward FDI data 


\section{Figure 5: High Income Affiliates}

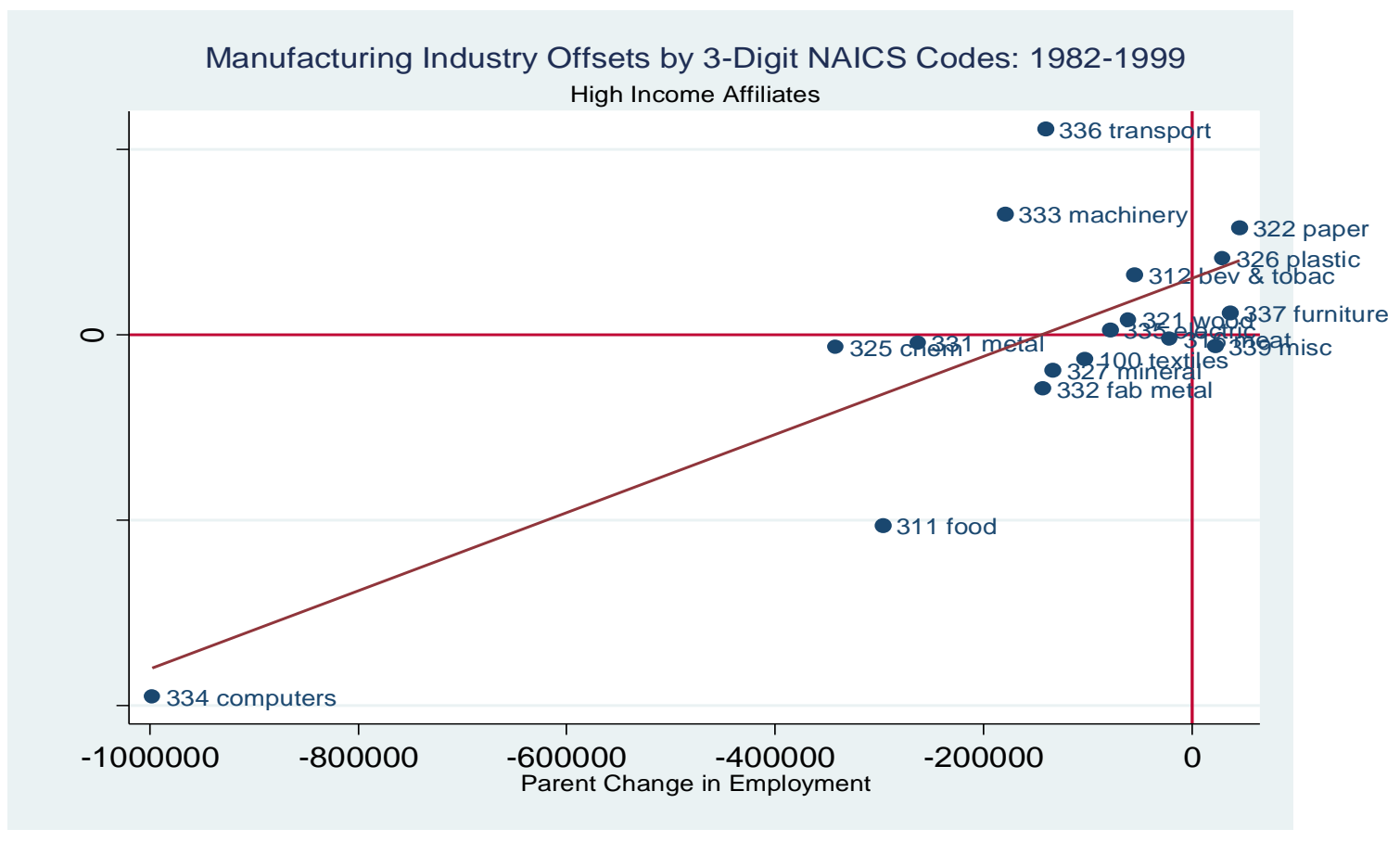

Source: Author's calculations based on BEA's outward FDI data 


\section{Figure 6: Medium/Low Income Affiliates}

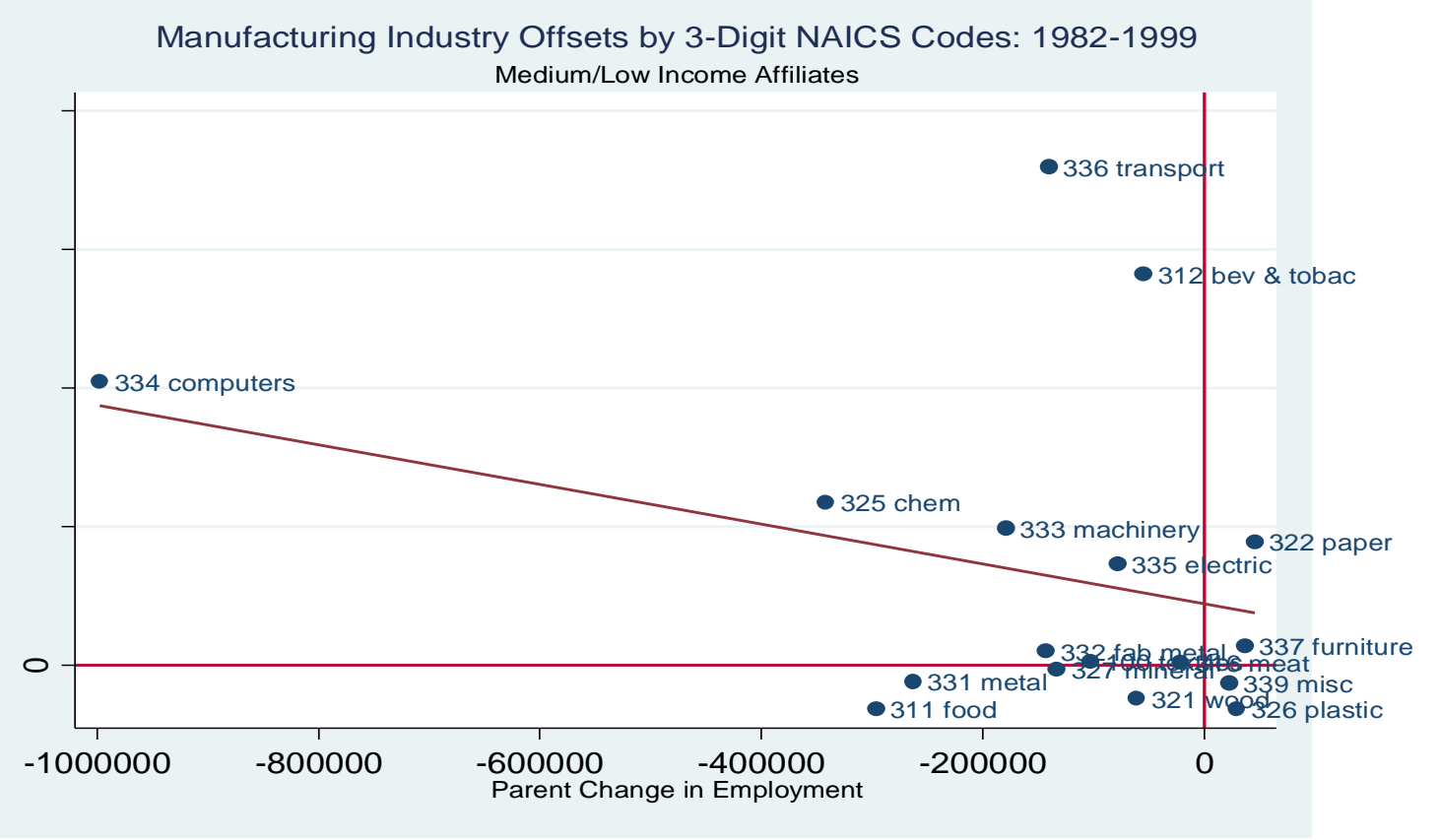

Source: Author's calculations based on BEA's outward FDI data 